\title{
Peran Pengasuh Panti Asuhan Membentuk Karakter Disiplin dalam Meningkatkan Kecerdasan Intrapersonal Anak
}

\author{
A. Mustika Abidin \\ Dosen IAIN Bone
}

\begin{abstract}
This article shows the role of caregiver of orphanage to form the character of discipline in improving children intrapersonal intelligence. The orphanage is a social institution that has a service program that is provided to answer the needs of the community in order to deal with social problems, especially the problems of poverty, stupidity and the problems of orphans, abandoned children who grow in the community. With the role of caregiver of the orphanage is to provide services based on the profession of social work to children who do not have a father or mother (orphan) or both (orphans) as a substitute for parents by loving, helping and guiding (nursing, preserving, and educating) the child is expected to form the character of discipline so as to improve the intrapersonal intelligence of the child (the intelligence in himself to recognize and understand himself).
\end{abstract}

Keywords: $\quad$ Role of Orphanage Caregiver, Discipline Character, Intrapersonal Intelligence

\section{Pendahuluan}

Panti asuhan merupakan lembaga sosial yang mempunyai peran melindungi dan membimbing anak-anak yatim, yatim piatu, terlantar dan kaum dhuafa untuk kesejahteraan hidup anak asuh. Hal ini karena anak merupakan dasar awal yang menentukan kehidupan suatu bangsa dimasa yang akan datang sehingga diperlukan persiapan generasi penerus bangsa dengan mempersiapkan anak untuk tumbuh dan berkembang secara optimal baik dalam perkembangan moral, fisik/motorik, kognitif, bahasa, maupun sosial emosional.

Panti Asuhan merupakan lembaga sosial nirlaba yang menampung, mendidik dan memelihara anak-anak yatim, yatim piatu dan anak telantar. Menurut Depsos RI Panti Sosial Asuhan anak adalah suatu lembaga usaha kesejahteraan sosial yang mempunyai tanggung jawab untuk memberikan pelayanan kesejahteraan sosial pada anak telantar dengan melaksanakan penyantunan dan pengentasan anak telantar, memberikan pelayanan pengganti orang tua/wali anak dalam memenuhi kebutuhan fisik, mental dan sosial kepada anak asuh sehingga memperoleh kesempatan yang luas, tepat dan memadai bagi pengembangan kepribadianya sesuai 


\section{An-Nisa', Volume XI Nomor 1 Januari 2018}

dengan yang diharapkan sebagai bagian dari generasi penerus cita-cita bangsa dan sebagai insan yang akan turut serta aktif dalam bidang pembangunan nasional ${ }^{71}$.

Dengan demikian, panti asuhan merupakan suatu lembaga yang berperan untuk membentuk perkembangan anak yang tidak memiliki keluarga ataupun yang tidak tinggal bersama dengan keluarga. Secara birokratis, program 100 hari kementrian Pendidikan Nasional Republik Indonesia dalam kabinet Indonesia Bersatu jilid II telah melahirkan program strategis dengan menggagas penyelenggaraan pendidikan karakter dan budaya bangsa.

Pendidikan karakter dapat dimaknai dengan pendidikan nilai, pendidikan budi pekerti, pendidikan moral, pendidikan watak yang bertujuan untuk memberikan keputusan baik-buruk, memelihara yang baik, dan mewujudkan kebaikan dalam kehidupan sehari-hari dengan sepenuh hati. Keadaan tersebut mendorong lembaga panti asuhan memiliki tanggung jawab untuk memberi pengetahuan, keterampilan dan pengembangan yang berkaitan dengan peningkatan pendidikan karakter anak khususnya membentuk karakter disiplin sehingga dapat meningkatkan kecerdasan intrapersonal anak (kecerdasan dalam diri untuk mengenali dan memahami dirinya sendiri).

\section{Peran Pengasuh Panti Asuhan}

\section{Pengertian Peran Pengasuh}

Istilah peran dalam "Kamus Besar Bahasa Indonesia" mempunyai arti pemain sandiwara (film), tukang lawak pada pemain, perangkat tingkah yang diharapkan dimiliki oleh orang yang berkedudukan di masyarakat. ${ }^{72}$ Peran menurut Soejono Soekanto adalah aspek dinamis dari kedudukan atau status.

Adapun pengertian pengasuh menurut Kamus Besar Bahasa Indonesia berarti menjaga (merawat dan mendidik) anak, membimbing (membantu dan melatih), memimpin (mengepalai, menyelenggarakan) dan menjaga supaya anak (orang) dapat berdiri sendiri. ${ }^{73}$ Jadi, pengasuh adalah orang yang melaksanakan tugas membimbing, memimpin dan mengelola.

\footnotetext{
${ }^{71}$ Departemen Sosial RI, Acuan Umum Pelayanan Sosial Anak di Panti Asuhan Sosial Anak, (Jakarta: Departemen Sosial RI, 2015), h. 4.

${ }^{72}$ Departemen Pendidikan Nasional, Kamus Besar Bahasa Indonesia Pusat Bahasa Ed.IV (Cet. I; Jakarta: PT Gramedia Pustaka Utama, 2008), h. 300.

${ }^{73}$ Departemen Pendidikan Nasional, Kamus Besar Bahasa Indonesia Pusat Bahasa Ed.IV, h. 310.
} 


\section{Pengertian Panti Asuhan}

Panti adalah rumah, tempat (kediaman), sedangkan asuhan adalah rumah tempat memelihara dan merawat anak yatim/yatim piatu dan sebagainya. ${ }^{74}$ Jadi, panti asuhan adalah tempat untuk mengasuh anak-anak yatim, piatu, atau yatim-piatu, bahkan anak-anak terlantar untuk dibina menjadi anak yang mandiri, bertanggung jawab, serta patuh dan berguna bagi masyarakat, nusa dan bangsa. Panti asuhan menjadi tempat pribadi manusia dimanusiawikan sebab panti asuhan mengasuh dan mendidik anak-anak yang seringkali disingkirkan oleh keluarga dan masyarakat.

Selain itu, berdasarkan Peraturan Menteri Sosial Republik Indonesia Nomor 21 Tahun 2013 tentang pengasuhan anak pada pasal 1 ayat 13 menjelaskan bahwa "Lembaga Kesejahteraan Sosial Anak yang selanjutnya disingkat LKSA adalah lembaga kesejahteraan sosial yang dibentuk oleh pemerintah, pemerintah daerah, atau masyarakat yang melaksanakan pelayanan pengasuhan dan perlindungan terhadap anak baik yang berada didalam maupun di luar Lembaga Kesejahteraan Sosial. ${ }^{75}$

\section{Fungsi Panti Asuhan}

Adapun fungsi dari panti asuhan antara lain:

a. Sebagai pusat pelayanan kesejahteraan sosial anak Panti asuhan berfungsi sebagai pemulihan, perlindungan, pengembangan dan pencegahan. fungsi pemulihan dan pengentasan anak ditujukan untuk mengembalikan dan menanamkan fungsi sosial anak asuh.

b. Sebagai pusat data dan informasi serta konsultasi kesejahteraan sosial anak

Fungsi konsultasi menitik beratkan pada intervensi terhadap lingkungan sosial anak asuh yang bertujuan di satu pihak dapat menghindarkan anak asuh dari pola tingkah laku yang sifatnya menyimpang.

c. Sebagai pusat pengembangan keterampilan (yang merupakan fungsi penunjang)

Pelayanan pengembangan adalah suatu proses kegiatan yang bertujuan meningkatkan mutu pelayanan dengan cara membentuk kelompok-kelompok anak dengan lingkungan sekitarnya, menggali semaksimal mungkin, meningkatkan kemampuan sesuai dengan bakat

\footnotetext{
${ }^{74}$ Safira Triantoro. Autis Pemahaman Baru Untuk Hidup Bermakna Bagi Orang Tua. (Jakarta: Graha Ilmu, 2015), h. 31.

${ }^{75}$ Peraturan Menteri Sosial Republik Indonesia Nomor 21 Tahun 2013 tentang Pengasuhan Anak
} 


\section{An-Nisa', Volume XI Nomor 1 Januari 2018}

anak, menggali sumber-sumber baik di dalam maupun luar panti semaksimal mungkin dalam rangka pembangunan kesejahteraan anak.

\section{Sifat Pelayanan Panti Asuhan Anak}

Sifat pelayanan sosial kepada anak melalui panti sosial asuhan anak (PSAA) mengandung sifat preventif, kuratif, dan rehabilitatif yang pelaksanaannya saling melengkapi dan saling menunjang. Adapun maksud dari sifat pelayanan tersebut:

\section{a. Preventif}

Pelayanan ini ditekankan untuk mencegah dan mengurangi masalah anak melalui berbagai upaya pencegahan baik primer, sekunder, maupun tersier. Pencegahan primer dimaksudkan sebagai upaya agar tidak terjadi masalah pada anak. Sekunder menekankan pada sifat mencegah agar masalah yang dihadapi anak tidak meluas sedangkan tersier menekankan agar masalah yang pernah muncul tidak tumbuh atau terulang kembali.

\section{b. Kuratif (Perlindungan)}

Pelayanan ini memandang bahwa setiap anak memiliki potensi kemampuan dan kekuatan yang perlu dilindungi dan dikembangkan. Oleh sebab itu, keanekaragaman pelayanan hendaklah disediakan oleh panti sosial asuhan anak (PSAA) yang memungkinkan diberikannya perlindungan yang memadai bagi setiap anak.

\section{c. Rehabilitatif}

Layanan ini memandang bahwa mengembalikan peranan anak pada situasi yang sehat adalah mutlak diperlukan dalam setiap pelayanan. Pelayanan rehabilitatif mengupayakan pemulihan anak memperoleh hak, sehingga yang bersangkutan mampu menampilkan kedudukan dan perannya dalam lingkungan sosial secara wajar.

\section{Karakter Disiplin}

\section{Pengertian Karakter Disiplin}

Karakter diartikan sebagai perilaku yang dilandasi oleh nilai-nilai berdasarkan norma agama, kebudayaan, hukum/konstitusi, adat istiadat, dan estetika. ${ }^{76}$ Dengan demikian, karakter adalah sebuah proses yang dilakukan untuk membentuk nilai-nilai dasar/karakter pada diri

\footnotetext{
${ }^{76}$ Muhammad Yaumi, Pendidikan Karakter: Landasan, Pilar dan Implementasi, h. 6.
} 
seseorang untuk membangun kepribadian orang tersebut, baik nilai karakter yang harus ada antara manusia dengan Tuhannya, nilai karakter yang harus ada antar sesama manusia, lingkungan maupun nilai karakter diri pribadi seseorang.

Istilah karakter berasa dari bahasa Latin character, yang berarti watak, tabiat, sifat-sifat kejiwaan, budi pekerti, kepribadian dan akhlak. ${ }^{77}$ Dalam bahasa Inggris, karakter diterjemahkan menjadi character yang berasal dari bahasa yunani yaitu charassein yang berarti to engrave. ${ }^{78}$ Kata to engrave bisa diterjemahkan mengukir, melukis, memahatkan, atau menggores sedangkan menurut terminologi karakter diartikan sebagai sifat manusia pada umumnya yang bergantung pada faktor kehidupanya sendiri. Jadi, karakter merupakan nilai-nilai yang berhubungan dengan Tuhan Yang Maha Esa, diri sendiri, sesama manusia, lingkungan dan kebangsaan yang terwujud dalam pikiran, sikap, perasaan, perkataan, dan perbuatan berdasarkan norma-norma agama, hukum, tata krama, budaya dan adat istiadat.

Disiplin berasal dari kata inggris yakni discipline yang berarti tertib, taat atau mengendalikan tingkah laku, penguasaan diri, kendali diri, latihan membentuk, meluruskan, atau menyempurnakan sesuatu, sebagai kemampuan mental atau karakter moral, hukum yang diberikan untuk melatih atau memperbaiki kumpulan atau sistem peraturan-peraturan bagi tingkah laku. ${ }^{79}$

Menurut Deni Damayanti disiplin adalah suatu sikap mental yang tercermin dalam perbuatan atau tingkah laku perorangan, kelompok atau masyarakat berupa ketaatan terhadap peraturan-peraturan atau ketentuan yang ditetapkan pemerintah atau etika, norma dan kaedah yang berlaku dalam masyarakat untuk tujuan tertentu ${ }^{80}$. Jadi, disiplin dapat dipahami sebagai kepatuhan untuk menghormati dan melaksanakan suatu sistem yang mengharuskan orang untuk tunduk kepada keputusan, perintah dan peraturan yang berlaku

Karakter disiplin merupakan perilaku yang dilakukan oleh seseorang dalam rangka mematuhi aturan yang ada. ${ }^{81}$ Karakter atau sikap disiplin dapat didefinisikan sebagai salah satu

\footnotetext{
${ }^{77}$ Musfah, Pendidikan Karakter: Sebuah Tawaran Model Pendidikan (Jakarta: Prenada Media, 2011), h.127.

${ }^{78}$ Asmaun Sahlan \& Angga Teguh Prasetyo, Desain Pembelajaran Berbasis Pendidikan Karakter (Yogyakarta: Ar-Ruzz Media, 2012), h. 25.

${ }^{79}$ Malayu Hasibuan, Manajemen Sumber Daya Manusia (Jakarta: Bumi Aksara 2009), h. 193

${ }^{80}$ Deni Damayanti, Panduan Implementasi Pendidikan Karakter (Yogyakarta: Araska, 2014), h. 17.

${ }^{81}$ Moh. Shocib, Membantu Anak Mengembangkan Disiplin Diri (Jakarta: Rineka Cipta, 2010), h. 21.
} 


\section{An-Nisa', Volume XI Nomor 1 Januari 2018}

karakter yang baik dan membawa seseorang pada hal yang baik. Dengan demikian, karakter disiplin adalah berkepribadian, berperilaku, bersifat, bertabiat, dan berwatak pada suatu keadaan di mana seseorang berada dalam keadaan tertib, teratur dan semestinya serta tidak ada pelanggaran-pelanggaran baik secara langsung maupun tidak langsung.

\section{Macam-macam Karakter Disiplin}

Disiplin adalah tindakan yang menunujukan perilaku tertib dan patuh pada berbagai ketentuan dan peraturan. Kedisiplinan dapat dilakukan diajarkan kepada anak di sekolah, di rumah maupun di dalam lembaga dengan cara membuat semacam peraturan atau tata tertib yang wajib dipatuhi oleh setiap anak. Peraturan dibuat secara fleksibel, tetapi tegas. Dengan kata lain, peraturan menyesuaikan dengan kondisi perkembangan anak serta dilaksanakan dengan penuh ketegasan. Apabila ada anak asuh yang melanggar, harus menerima konsekuesi yang telah disepakati. ${ }^{82}$ Macam-macam karakter disiplin menurut M. Furqon Hidayatullah:

\section{a. Disiplin Waktu}

Disiplin waktu menjadikan sorotan utama bagi seorang pengasuh dan anak asuh. Waktu masuk sekolah biasanya menjadi parameter utama kedisiplinan. Kalau masuk sekolah sebelum bel dibunyikan, berarti disebut orang yang disiplin. Kalau masuk pas dibunyikan, bisa dikatakan kurang disiplin, dan kalau masuk setelah bel dibunyikan, maka dinilai tidak disiplin/menyalahi aturan madrasah yang telah ditentukan, karena itu jangan menyepelekan disiplin waktu ini,

\section{b. Disiplin Sikap}

Disiplin mengontrol perbuatan diri sendiri menjadi startingpoint untuk menata perilaku orang lain. Misalnya, disiplin tidak tergesa-gesa dan gegabah dalam bertindak.

\section{c. Disiplin Belajar}

Belajar juga membutuhkan kedisiplinan dan keteraturan. Dengan disiplin belajar setiap hari, lama kelamaan akan menguasai bahan itu. Keteraturan ini hasilnya akan lebih baik daripada belajar hanya pada saat akan ujian saja. ${ }^{83}$

\footnotetext{
${ }^{82}$ Muhammad Fadlillah dan Lilif Mualifatu Khorida, Pendidikan Karakter Anak Usia Dini (Yogyakarta: Pustaka Pelajar, 2012), h.192.

${ }^{83}$ M. Furqon Hidayatullah, Pendidikan Karakter: Membangun Peradaban Bangsa, (Surakarta: Yuma Pressindo, 2010), h. 45-49.
} 
Untuk itu, bila disiplin diharapkan mampu mendidik anak untuk berperilaku sesuai dengan standar yang ditetapkan kelompok sosial, ia harus mempunyai empat unsur pokok, apa pun cara mendisiplin yang digunakan, yaitu: (1) peraturan sebagai pedoman perilaku, (2) konsistensi dalam peraturan, (3) cara yang digunakan untuk mengajarkan dan memaksakanya, dan hukuman untuk pelanggaran peraturan, dan (4) penghargaan untuk perilaku yang baik yang sejalan dengan peraturan yang berlaku

\section{Kecerdasan Intrapersonal}

\section{Pengertian Kecerdasan Intrapersonal}

Kecerdasan intrapersonal merupakan kemampuan seseorang untuk mengenali dan mengembangkan potensi serta mengekspresikan dirinya atau kemampuan untuk memahami diri sendiri dan menggunakan pemahaman dalam kehidupan. ${ }^{84}$ Jadi, kecerdasan intrapersonal adalah kemampuan untuk memahami diri sendiri dan bertanggung jawab atas kehidupannya sendiri.

\section{Aspek-aspek Kecerdasan Intrapersonal}

Aspek pertama yang terdapat dalam kecerdasan intrapersonal adalah mengenali diri sendiri. Ada beberapa karakteristik cara mengenali diri sendiri:

a. Kesadaran diri emosional

Kesadaran diri emosional adalah bagian dari bebas buta emosi dan sebuah tanda keseimbangan dan kedewasaan. Ini berarti bersikap jujur terhadap diri sendiri dan terhadap orang lain.

\section{b. Keasertifan}

Sikap asertif sering disalahartikan dengan sikap agresif. Keagresifan adalah melakukan sesuatu dengan cara anda sendiri tanpa peduli apa atau siapapun yang menghalanginya sedangkan keasertifan adalah keterampilan emosional untuk secara bebas dan tepat mengungkapkan pikiran, perasaan, pendapat dan keyakinan anda.

\footnotetext{
2012), h. 149.
}

${ }^{84}$ Purwa Atmmaja Prawira, Psikologi Pendidikan Dalam Perspektif Baru (Jogjakarta: Ar-Ruzz Media, 


\section{An-Nisa', Volume XI Nomor 1 Januari 2018}

c. Harga diri

Harga diri atau citra diri adalah karakteristik inteligensi emosi yang menunjukkan penilaian diri yang tinggi dan merupakan sumber penting bagi rasa percaya diri. Hal ini berarti memiliki perasaan-perasaan yang sesuai, perasaan yang baik tentang siapa diri kita sebagai pribadi, kita merasa puas dengan diri kita dan kita sendiri terpuaskan.

d. Kemandirian

Kemandirian adalah sebuah sifat yang dihubungkan dengan orang-orang yang suka memulai. Orang yang bebas (tidak bergantung) memiliki ciri-ciri sebagai berikut: (1) orang yang mengarahkan diri sendiri dan mengendalikan diri sendiri,(2) memiliki inisiatif, (3) tampak bebas dan tidak bergantung secara emosional, (5) tahu bagaimana mengurus diri, (6) percaya diri dalam membuat rencana,(7) dapat membuat keputusan-keputusan penting untuk diri mereka sendiri,(8) tidak hancur berantakan dan menunggu orang lain menolong.

Aspek kedua yang terkandung dalam kecerdasan intrapersonal adalah mengetahui apa yang kita inginkan. Orang yang cerdas cenderung mengetahui apa yang mereka inginkan dan kemana tujuan hidup mereka. Aspek terakhir yang terkandung dalam kecerdasan intrapersonal adalah Mengetahui Apa yang Penting. Setelah melewati aspek kedua, mengetahui apa yang diinginkan, tidak hanya tujuan-tujuan yang menjadi lebih jelas dan kurang bermasalah, kita juga akan memiliki kecenderungan untuk menilai kembali nilai-nilai yang sudah didapatkan. Tujuantujuan yang dipertimbangkan dan nilai-nilai yang mendasarinya akan menemukan urutan kepentingannya sendiri. Untuk mengetahui apa yang penting, pada bagian ini akan memusatkan pada nilai-nilai yang dimiliki oleh pribadi. Sebuah nilai adalah sesuatu yang penting bagi. Misalnya, jika kita mempunyai sebuah nilai "kejujuran", itu berarti bahwa kita menganggap penting untuk bersikap jujur. Nilai ini merupakan sebuah tujuan atau maksud yang utama. Artinya semua tujuan kita harus cocok dengan nilai ini. Jika tidak, kita tidak akan mengalami perasaan puas dan bahagia meskipun kita melakukannnya dengan sungguh-sungguh dan tulus ikhlas. $^{85}$

\footnotetext{
${ }^{85}$ Thomas Armstrong, Identifying And Developing Your Multiple Intelligences (Menemukan dan Meningkatkan Kecerdasan Anda Berdasarkan Teori Multiple Intelligences, terj. T. Hermaya (Jakarta: Gramedia Pustaka Utama, 2012), h. 118-120.
} 


\section{Penutup}

Panti asuhan merupakan suatu lembaga yang berperan untuk membentuk perkembangan anak yang tidak memiliki keluarga ataupun yang tidak tinggal bersama dengan keluarga. Anakanak panti asuhan diasuh oleh pengasuh yang menggantikan peran orang tua dalam mengasuh, menjaga dan memberikan bimbingan agar anak menjadi manusia dewasa yang berguna dan bertanggung jawab atas dirinya dan terhadap masyarakat di kemudian hari. Untuk itu, salah satu peran pengasuh panti asuhan yaitu membentuk karakter disiplin pada anak.

Pendidikan karakter adalah proses pemberian tuntutan kepada anak untuk menjadi manusia seutuhnya yang berkarakter dalam dimensi hati, pikir, raga, serta rasa dan karsa. Pendidikan karakter dapat dimaknai dengan pendidikan nilai, pendidikan budi pekerti, pendidikan moral, pendidikan watak yang bertujuan untuk memberikan keputusan baik-buruk, memelihara yang baik, dan mewujudkan kebaikan dalam kehidupan sehari-hari dengan sepenuh hati. Keadaan tersebut mendorong lembaga panti asuhan memiliki tanggung jawab untuk memberi pengetahuan, keterampilan dan pengembangan yang berkaitan dengan peningkatan pendidikan karakter anak khususnya membentuk karakter disiplin sehingga dapat meningkatkan kecerdasan intrapersonal anak (kecerdasan dalam diri untuk mengenali dan memahami dirinya sendiri) karena dengan pemahaman diri sendiri sangat baik untuk membantu mengembangkan potensi dalam diri dan mambantu untuk dapat mengekspresikan diri dengan lebih baik.

\section{Daftar Rujukan}

Armstrong, Thomas. Identifying And Developing Your Multiple Intelligences (Menemukan dan Meningkatkan Kecerdasan Anda Berdasarkan Teori Multiple Intelligences, terj. T. Hermaya Jakarta: Gramedia Pustaka Utama, 2012.

Damayanti, Deni. Panduan Implementasi Pendidikan Karakter. Yogyakarta: Araska, 2014. Departemen Pendidikan Nasional, Kamus Besar Bahasa Indonesia Pusat Bahasa Ed.IV. Cet. I; Jakarta: PT Gramedia Pustaka Utama, 2008. 


\section{An-Nisa', Volume XI Nomor 1 Januari 2018}

Departemen Sosial RI, Acuan Umum Pelayanan Sosial Anak di Panti Asuhan Sosial Anak. Jakarta: Departemen Sosial RI, 2015.

Fitri, Agus Zainul. Pendidikan Karakter Berbasis Nilai \& Etika di Sekolah. Yogyakarta: Ar-Ruz Media, 2012.

Hasibuan, Malayu. Manajemen Sumber Daya Manusia. Jakarta: Bumi Aksara 2009.

Hidayatullah, M. Furqon. Pendidikan Karakter: Membangun Peradaban Bangsa,. Surakarta: Yuma Pressindo, 2010.

Muhsin, Mari Mencintai Anak Yatim. Jakarta: Gema Insani Press, 2013.

Musfah. Pendidikan Karakter: Sebuah Tawaran Model Pendidikan. Jakarta: Prenada Media, 2011.

Peraturan Menteri Sosial Republik Indonesia Nomor 21 Tahun 2013 tentang Pengasuhan Anak

Sahlan, Asmaun \& Angga Teguh Prasetyo. Desain Pembelajaran Berbasis Pendidikan Karakter. Yogyakarta: Ar-Ruzz Media, 2012

Shochib, Mochtar. Pola Asuh Orang Tua. Jakarta: Rineka Cipta, 2016.

Shocib, Moh. Membantu Anak Mengembangkan Disiplin Diri. Jakarta: Rineka Cipta, 2010.

Triantoro, Safira. Autis Pemahaman Baru Untuk Hidup Bermakna Bagi Orang Tua. Jakarta: Graha Ilmu, 2015.

Yaumi, Muhammad. Pendidikan Karakter: Landasan, Pilar dan Implementasi. Cet.I; Jakarta: Kencana, 2014. 